\title{
Bureaucracy Reform : The Low Performance of Goverment Bureaucracy in the Perspektive of Public Service in Indonesia
}

\author{
Heri Kurniawansyah HS \\ Gadjah Mada University, Indonesia
}

\begin{abstract}
Entrying the new people that have highly educated in the bureaucracy level, and supported by a tremendous technological and communications revolution, has not been able to provide significant changes to the public service.The bureaucracy performance of the direct democracy era has become a policy issue that is very strategic, because the improvement of bureaucracy performance has a impact that is very strategic on the state's order, especially in the field of economy and politic. This paper presents a causes the low performanceof government bureaucracy in the perspective of public service. The findings are (1) the problem of leadership in bureaucracy of Indonesia, (2) unclear division of power (hierarchical), (3) limited discretionary authority (authoritarian culture still strong), and (4) incentive system is not good.
\end{abstract}

Keywords: Bureaucracy Reform, Low Performance, Public Service, Government

\section{Introduction}

The New Order Regime has placed the government's bureaucracy as a tool of authority rather than the servants of its people. The bureaucracy paradigm of the New Order Era became the mouthpiece of the power of the rulers, so the bureaucrats were more placed themselves as rulers when they were supposed to be servants of society (Dwiyanto, 2006). As for the problems such as the emergence of corruption behavior, collusion and nepotism (KKN). In the end there is disparity of justice in society, and resulted in the level of trust and legitimacy of society to the bureaucracy became very low.

In 1998, the new order regime was successfully overthrown through the student revolution. Indonesia also successfully conducted the first public election directly. The purpose of all these events is the existence of public expectations to the government for bureaucratic order, including public service to be better based on democratic values. Along with the new spirit of the birth of a new system, it becomes the starting point of improvement of every aspect of government, one of the most important is bureaucratic reform. Reforms are continually campaigned and echoed, from the central government to the village government in a spirit of effectiveness, efficiency and accountability. But apparently the spirit of reform has not had a significant impact for the community. The political world's toil has always been the main concern of the government. The public's expectation for getting a good public service that efficient, effective, and accountable is far from reality.

The centralized powers that have been divided into each region have also become a new enthusiasm for improving public services, but ironically, the entrying of new people with higher education on average, and supported by the entrying of new people with higher education on average has not yet had an impact significant to public services. For the provincial government, from 33 provincial governments, as many as 39.39 percent or 13 provinces are included in the green zone with high adherence predicate. A total of 39.39 percent or 13 provinces were included in the yellow zone with moderate adherence and 21.21 percent or 7 provinces were included in the red zone with a low adherence predicate. This realization is still far target achievement in 2016 by 70 percent. 
In addition, from 85 district governments surveyed, indicating that as many as 29 percent or 25 district administrations entered the red zone with a low compliance predicate, 53 percent or 45 district administrations entered the yellow zone with moderate adherence and 18 percent or 15 district administrations in a green zone with a high adherence predicate. The results of observations on the physical appearance of public services in each service unit to provide public service attributes indicate that the levels of government and local government compliance with public service standards are still low.

The Hong Kong-based Political and Economic Risk Consultancy (PERC) examines that the Indonesian bureaucracy is considered the worst and has not improved significantly. Of course much will be due to poor public services in the government bureaucracy, and all that will lead to the slow pace of development in all sectors. Agus Dwiyanto and his colleagues in his book entitled "Reform of Public Bureaucracy in Indonesia", mentioned that there are two major implications for the poor performance of the bureaucracy, namely economic implications and political implications. Poor performance of bureaucracy on the economy is usually always a factor that determines the decrease of investment interest (Wicaksono, 2006), whereas investment is one of the important conditions that the country needs to get out of the prolonged crisis. While the poor performance of the bureaucracy on politics resulted in a decrease in the level of public trust to the government (Kusumasari, 2006), consequently the government is difficult to implementate its development program.

Based on these issues, in this paper will focus on the study of what causes the low performance of government bureaucracy, with the aim for determining the causes of low performance of government bureaucracy in public service. While in the data collection, the authors conducted empirical analysis, literature study, and interviews with relevant experts and stakeholders.

\section{Result and Discussion}

\subsection{Leadership problems}

The problem of public service is not caused by poor management, but in fact the main problem is the issue of leadership (Pereira in Keban, 2004). In building the bureaucracy, the main strategic aspect that must be addressed is the quality of bureaucratic leadership, because the managing leadership is the greatest investment for organizational progress (Keban, 2014). This aspect must be addressed through leadership development, because the role of the leader is vital and a source of inspiration and innovation, as well as being a mediator for the troubled parties (Gerson, 2006).

So many cases are happening in various regions about poor public services. Leaders will be the target of criticism, because leaders are most responsible in an organization. The author pays attention to various government offices, so many employees are relaxed when the time are actively working. Sometimes they read newspapers, play games, leave the office during working hours, huddling, and so on, while many people are needing a services in their offices. This happen because the leader is not firmly to subordinates, so that the subordinates is not controlled and doing a casual. As a result, public services is not optimal and tend to be slow. These criticisms are often leveled by students, and other societies through social media, even demonstrating to the poor public services, but these behaviors are still recurring.

The phenomenon can also be viewed in macro in various online news, print media, social media, and television media. The problem in Indonesia is nursery the seeds of leaders and managers in total and maximum received less attention from the government. Various leadership training have been doing, but these programs are sometimes more project-oriented and less directed at improving the ideal leader posture for bureaucracy (Keban, 2014). If so continues to be left, then in the future there will be a leadership crisis, and public service will remain a classic problem that will not be resolved. 
TABLE I: Form of sanction applied in the institution : Taken from 3 provinces of the 3 major islands in Indonesia

\begin{tabular}{|l|c|c|c|}
\hline & West Sumatra & Yogyakarta & South Sulawesi \\
\hline Scolded the boss/leadership & 7,8 & 5,0 & 11,6 \\
\hline Warned the leadership & 82,4 & 87,7 & 74,1 \\
\hline Delay in promotio / salary & 0,4 & 0,7 & 0,4 \\
\hline
\end{tabular}

From the table, the most dominant sanction given is only a warning from the boss. the sanctions does not provide changes in the performance of bureaucratic apparatus. This leadership issue also gave birth a paternalistic culture in the bureaucracy. Political elites, officials, or people who know them often receive preferential treatment in public services. The term "insiders" emerged in the bureaucracy. This means that "insiders" serve as an entrance to the acceleration of public services, especially for certain people (families, political officials, people closest, and others). The conditions show the existence of "favoritism" in public services, which resulted in disruption of public services to other ordinary people. The phenomenon is not separated by the attitude of leadership that is still low in the bureaucracy.

\subsection{Unclear Division of Power (Hierarchical)}

Bureaucracy reforms to excellent public services must take account of clear division of authority. If the authority in the bureaucracy is not clear, it is very disturbing public service process for the community. A leader or authority in government offices often has working/assignment or activities in out of their office, such as meetings with regent / governor, out-of-town work visit, and other field assignments. On the other hand the authority is entirely on the leadership, consequently the people who take care of the documents are always hampered by the head of the office who usually is not in his office.

The existence of powerful authority on the leadership is certainly caused by the bureaucracy structure that is still very hierarchical. Hierarchical bureaucracy structure encourage a concentration of power and authority on the boss so that the bureaucrats (street level bureaucrats) often do not have adequate authority (Ratminto, 2014). As a result, street level bureaucrats are unable to respond to any dynamics that develop in the process of public service.

Often we hear sentences that come out of the mouth of street level bureaucrats who say "sorry, that's not our authority, maybe you should just wait for our leader". If the leader has a task outside the city for a week, then during that week also the public must wait. This phenomenon occurs frequently in the process of public service in various regions. The distant rural community with the city must go back and forth to take care of something that should be completed in one day, but sometimes it can only be completed in weeks, months, and even years. Materially people are severely disadvantaged by system like that, especially for rural community. This is caused by unclear authority given to subordinates

Not only the internal authority of the organization remains unclear, the division of authority between central, provincial and district / city governments is also unclear. Many government offices in regencies whose authority is located in the provincial government, so the public service process tends to slow, because the affairs of people who are in the district should be taken care of to the province. Public affairs that must be taken care of to the provincial government will sacrifice the time, financial and especially mileage that is not near to the district.

Therefore it is necessary to improve the good structure. Improved bureaucracy structure is closely related to the arrangement of differentiation (vertical and horizontal), authority dispersion system, and formality level (Keban, 2007). Structural models such as self-managing teams, organizational design processes, virtual organizations, and organizational networks (Champoux, 2003) can be adopted as models for improving organizational structures according to the environment and organizational capabilities. 


\subsection{Limited Discretionary Authority (Authoritarian Culture Still Strong)}

This factor is one of the strengthening factors in the achievement of bureaucratic reform. Discretion is the space of Steert Level Bureaucrat in interpreting his duty widely or the freedom to interpret the way it works as it benefits the service user or accelerate, and facilitate the community itself as a group of people served. But the problem is that the discretion authority is very limited to be owned by street level bureaucrats in Indonesia.

Not all people understand the rules, not all people understand about the bureaucracy, especially the community that exist in remote areas. They only want their affairs through public service quickly and well, let alone the distance from the village to the city is so far. In such conditions it is necessary creativity and innovation of subordinate employees to speed up service to the community through what is called a discretion.

The field analysis that the rigid bureaucracy is caused by procedures and regulations is the commander in the bureaucracy, and it is the dominant indicator, so the initiative or the courage to make quick and concrete decisions tends is not to exist. The courage to develop creativity in an atmosphere that should be able to develop creativity in public service is not there. A bureaucracy like this would be very difficult to deal with the dynamics in such a high society (Tamtiari, 2006), whereas bureaucracy is actually a tool to facilitate the implementation of government policies in the service of society (Said, 2007).

In addition, bureaucratic officials still position themselves as ruler rather than as servants of society, consequently bureaucracy officials feel themselves the most needed person. That is what is called authoritarian culture in bureaucracy. As a result, people have low bargaining power when faced with government and bureaucracy (Noah, 2006). The lack of bureaucratic capacity to carry out these problems of public services has greatly added to the crisis of public confidence in the bureaucracy in Indonesia. The authoritarian culture also causes the limited of discretion authority of street level bureaucrats, because bureaucracy officials still consider themselves that all forms of authority are in the bureaucracy. great bureaucracy power and coupled with limited discretion will give rise to a corrupt bureaucracy (Klitgaard in Masri Maris, 2002).

The findings of Indonesia Corruption Watch (ICW) put bureaucrats as the most corrupt actors in 2010-2016. At least around 3,417 Bureaucrats are designated as suspects of corruption cases in a number of areas. According to The Global Competitiveness Report 2016-2017 released by the World Economic Forum, Indonesia is ranked 41 st out of 138 countries. Indonesia is under ASEAN countries, such as Singapore, Malaysia and Thailand (Kompas.com, 2017). The report states, corruption and inefficiency problems of bureaucracy become one of the biggest obstacles in doing business in Indonesia. As a result of corrupt actions conducted by ASN, employers must incur additional costs to facilitate the overly complex bureaucracy.

\subsection{Insetif System is Not Good}

The powerful authority from superiorshas erased instentives for street level bureaucrats (lack of reward and punishment). Thus the subject greatly affects the motivation of performance in the bureaucracy. The facts of the field show that there are new thoughts in street level bureaucrats that "busy and tired people work, just the same wages as those who do not work". As a result, the drive to achieve results and performance tends to be low in the life of the public bureaucracy. Such a scene would not be found in a private bureaucracy. In private bureaucracy, who performs and works maximally, they will get incentives as a form of appreciation to the subordinate, so that the motivation of work also increases. While in the government bureaucracy, there is or nothing is served, they still receive wages according to rank and class, consequently emerging "mental blocks" from subordinates / staff, where they think the more they are creative, the more workload is given while the wages which they receive is just the same as the non-creative.

Incentive system is an important element in an organization in order to increase the work motivation in achieving the desired work performance, because that incentive is determinant of performance of government bureaucratic apparatus (Emelia, 2006). The incentive system in the government bureaucracy should be able to enliven the private pattern of respecting its employees. Provision of incentives must also be done openly and 
associated with work performance. Thus will bring stimulation of street level bureaucrats to improve its performance.

TABLE II: Employee reasons improve work performance : Taken from 3 provinces

\begin{tabular}{|l|c|c|c|}
\hline & West Sumatra & Yogyakarta & South Sulawesi \\
\hline Increased revenue & 7,1 & 10,8 & 12,9 \\
\hline Obligations to duty & 7,1 & 8,9 & 4,1 \\
\hline $\begin{array}{l}\text { Service and community } \\
\text { service }\end{array}$ & 9,7 & 14,4 & 9,5 \\
\hline Award from the boss & 4,5 & 2,6 & 8,5 \\
\hline
\end{tabular}

From the table, the position of increased income or incentive is one of the important factors in improving job performance. the three provinces are representative of the provinces of the 3 major islands in Indonesia.

\section{Conclusion}

Public services that occur in the bureaucracy in Indonesia is still very low, whereas the state system is getting better. the inclusion of young people who have high education and understanding of technology has not provided significant changes in the process of public service. some of the factors that cause it to happen are the leadership problems in the bureaucracy itself, the problem of unclear and highly hierarchical division of authority, the limitation of discretionary authority for street level bureaucrats so that authoritarian culture is still very strong, and incentive systems are not good. if all these problems continue to be ignored, then the problems of public service and bureaucratic reform will not be solved properly.

\section{Acknowledgements}

The author wish to thank to LPDP Scholarship of Indonesia for providing financial support. Much thank to all of my classmate in my campus that much give me a information about condition of bureaucracy problem in each their province/region. The information too help me for increasing data of my paper. Much thank again to my lecturer that much give me their science and referral.

\section{References}

[1] Campoux, J.E. 2003. Organizational Behavior : Essential Tenets. Mason, Ohio : Thompson

[2] Dwiyanto, Agus, dkk. 2006. Reformasi Birokrasi Publik Di Indonesia. Yogyakarta : Gadjah Mada University Press

[3] Denhardt, J.V, and R.B. Denhart. 2007. The New Public Service: Serving, not Steering, Expanded Edition. New York : M.E. Sharpe

[4] Indiahono, Dwiyanto. 2008. Perbandingan administrasi Publik : Model, Konsep, dan Aplikasi. Yogyakarta : Gava Media

[5] Keban, Y.T. 2007. Membangun Kerjasama Antar Pemerintah Daerah Dalam Era Otonomi. Warta Gubernur Jurnal Otonomi dan Pembangunan Daerah, (1) Januari

[6] Keban, Y.T. 2014. Enam Dimensi Strategis Administrasi Publik : Konsep, Teori, dan Isu. Yogyakarta : Gava Media

[7] Kumorotomo, Wahyudi, dan Pramusinto, Agus. 2009. Governance Reform di Indonesia : Mencari Arah Kelembagaan Politik Yang Demokratis dan Birokrasi Yang Profesional : Yogyakarta : Gava Media

[8] Lipsky, Michael (2010). Street Level Bureaucracy: Dilemmas of the Individual in Public Services. 30th Anniversary Expanded Edition. The Russell Sage Foundation: New York, NY

[9] Meita Istiandi dan Darmanto (2009). Universitas Terbuka Jurusan Ilmu Administrasi Negara. Jurnal Ilmu Administrasi Negara, Volume 9, Nomor 2, Juli 2009: 123 - 133 
[10] Osborne, David and Peter Plastrik. 1997. Banishing Bureaucracy : The Five Strategies For Reiventing Government. California : Addsion-Wesley Publishing Company, Inc.

[11]Tummers, L.G. \& Bekkers, V.J.J.M. (2014). Policy implementation, street-level bureaucracy and the importance of discretion. Public Management Review, 16(4), 527-547

https://doi.org/10.1080/14719037.2013.841978

[12] Http://nasional.kompas.com/read/2017/04/07/17595581/kegagalan.reformasi.birokrasi. Diakses tanggal 31 Desember 2017.

[13] Http://kebebasaninformasi.org/2010/10/26/kinerja-birokrasi-pelayanan-publik/.

Diakses tanggal 20 Februari 2018.

[14] Https://tirto.id/rapor-merah-pelayanan-publik-di-indonesia-b8zr. Diakses tanggal 18 Februari 2018. 